Aleksander M. Garlicki', Mirosław Jawieńn', Stawomir Pancewicz'2, Anna Moniuszko-Malinowska ${ }^{2}$, Anna Kalinowska-Nowakl, Monika Bociaga-Jasik ${ }^{l}$

\title{
MANAGEMENT OF BACTERIAL SKIN AND SOFT TISSUE INFECTIONS
}

\author{
POSTĘPOWANIE W ZAKAŻANIACH BAKTERYJNYCH SKÓRY \\ I TKANEK MIĘKKICH
}

\author{
${ }^{1}$ Jagiellonian University Medical College, Department of Infectious and Tropical Diseases \\ ${ }^{2}$ Medical University of Białystok, Department of Infectious Diseases and Neuroinfections \\ ${ }^{1}$ Uniwersytet Jagielloński Collegium Medicum, Klinika Chorób Zakaźnych i Tropikalnych \\ ${ }^{2}$ Uniwersytet Medyczny w Białymstoku, Klinika Chorób Zakaźnych i Neuroinfekcji
}

\begin{abstract}
Skin and soft tissue infections (SSTIs) are a group of diseases usually caused by bacteria, and connected with different clinical picture, course, and prognosis. The increasing incidence of SSTIs is associated mainly with aging of the population, the increasing number of metabolic diseases, especially diabetes mellitus, as well as cardiovascular diseases. Although SSTIs are often benign and usually does not require medical consultations, some of them may cause a systemic infection. In this situation, knowledge of the principles of diagnostic work-up and therapy is essential. The principles of recognition and treatment of skin and soft tissue infections, including new biocidal drugs, are presented.
\end{abstract}

Key words: skin and soft tissue infections, new antibiotics

\section{STRESZCZENIE}

Zakażenia skóry i tkanek miękkich (ZSTM) stanowią grupę chorób, najczęściej o etiologii bakteryjnej, charakteryzujących się zróżnicowanym obrazem klinicznym, przebiegiem i rokowaniem. Coraz częstsze występowanie ZSTM wiąże się m.in. ze starzeniem się populacji, narastaniem częstości występowania chorób metabolicznych, zwłaszcza cukrzycy, a także chorób układu sercowo-naczyniowego. Jakkolwiek część ZSTM ma przebieg łagodny i najczęściej nie wymaga wizyty lekarskiej, to niektóre manifestacje mogą przybrać postać zakażenia ogólnoustrojowego. W tej sytuacji znajomość zasad diagnostyki i terapii jest niezbędna. Przedstawiono zasady rozpoznawania i leczenia zakażeń skóry i tkanek miękkich, z uwzględnieniem nowych leków biobójczych.

Słowa kluczowe: zakażenia skóry i tkanek miękkich, nowe antybiotyki

\section{INTRODUCTION}

Skin and soft tissue infections are one of the most common reasons for visiting a doctor, and in the US, they account for more than 14 million visits to a Family doctor or an emergency room (1). Approximately 10\% of patients require hospitalization (2).

In recent years, there has been an increase in skin and soft tissue infections, primarily due to prolongation of human life and the presence of civilization disorders such as obesity and diabetes mellitus (3).
WSTĘP

Zakażenia skóry i tkanek miękkich należą do jednych z częstszych przyczyn zgłaszania się do lekarza, a w USA są przyczyną ponad $14 \mathrm{mln}$ wizyt u lekarza rodzinnego lub w szpitalnych oddziałach ratunkowych (1). Około $10 \%$ pacjentów wymaga hospitalizacji (2).

W ostatnim okresie obserwuje się wzrost zachorowań na zakażenia skóry i tkanek miękkich, co wynika przede wszystkim z wydłużenia życia oraz występowania chorób cywilizacyjnych, takich jak otyłość i cu- 
Additionally, an increasing number of infections, including community acquired infections, are caused by multi-drug resistant strains of microorganisms, in particular methicillin-resistant Staphylococcus aureus. Staphylococcal infections are among the most common infections in humans due to frequent skin and mucosal colonization, high genomic variation and easy acquiring of antibiotic resistance genes. It is currently estimated that approximately $60 \%$ of all skin and soft tissue infections are caused by methicillin-resistant Staphylococcus aureus (4).

\section{DEFINITION AND CLASSIFICATIONS}

Most skin and soft tissue infections are caused by breaking the integrity of the skin barrier due to trauma, surgery or increased tissue tension secondary to fluid retention. These infections may also result from the spread of microorganisms via blood or lymph from a distant site $(5,6)$.

Skin and soft tissue infections can be classified based on their nature $(5,7)$ :

1. Purulent

- furuncles

- furunculosis

- abscesses

2. Non-purulent

- erysipelas

- superficial cellulitis

- necrotizing fasciitis

3. Non-necrotizing

- impetigo

- furuncle

- furunculosis

- infections associated with animal or human bites

- erysipelas

- superficial cellulitis

- surgical site infection

- skin abscesses

4. Necrotizing

- necrotizing myositis and fasciitis

- gas gangrene

- Fournier gangrene

- gangrenous cellulitis

5. Non-complicated

- erysipelas

- furuncle

- furunculosis

- superficial cellulitis

- impetigo

- folliculitis

- superficial abscesses

- traumarelated infections

6. Complicated

- deep large abscesses krzyca (3). Dodatkowo coraz więcej zakażeń, również pozaszpitalnych wywoływanych jest przez wielolekooporne szczepy drobnoustrojów, zwłaszcza przez metycylinooporne szczepy Staphylococcus aureus. Zakażenia gronkowcowe należą do najczęstszych zakażeń u ludzi, co jest następstwem częstej kolonizacji skóry i błon śluzowych, dużej zmienności genomu oraz łatwemu przyswajaniu genów oporności na antybiotyki. Ocenia się, że obecnie ok. $60 \%$ wszystkich zakażeń skóry i tkanek miękkich spowodowanych przez szczepy metycylinooporne gronkowca złocistego (4).

\section{DEFINICJA I KLASYFIKACJE}

Większość zakażeń skóry i tkanek miękkich pojawia się na skutek naruszenie ciągłości bariery ochronnej skóry przez uraz, zabieg chirurgiczny lub zwiększone napięcie tkankowe wtórne do zastoju płynów. Zakażenia te mogą być również wynikiem rozprzestrzeniania się drobnoustrojów drogą krwiopochodną lub limfopochodną z odległego ogniska $(5,6)$.

Zakażenia skóry i tkanek miękkich można zaklasyfikować ze względu na ich charakter $(5,7)$ :

\section{Ropne \\ - czyraki \\ - czyraczność \\ - ropnie}

2. Nieropne

- róża

- powierzchowne zapalenia tkanki łącznej (cellulitis)

- martwicze zapalenie powięzi

\section{Niemartwicze}

- liszajec

- czyrak

- czyraczność

- zakażenia związane $\mathrm{z}$ pogryzieniem przez zwierzęta lub człowieka

- róża

- powierzchowne zapalenie tkanki łącznej (cellulitis)

- zakażenia miejsca operowanego

- ropnie skórne

\section{Martwicze}

- martwicze zapalenie mięśni i powięzi

- zgorzel gazowa

- zgorzel Fouriera

- zgorzelinowe zapalenie tkanki łącznej

5. Niepowiklane

- róża

- czyrak

- czyraczność

- powierzchowne zapalenie tkanki łącznej

- liszajec

- zapalenie mieszków włosowych 
- necrotizing fasciitis

- gas gangrene

- Fournier gangrene

- infections resulting from animal or human bites

\section{Based on course}

- mild

- moderate

- severe

Skin and soft tissue infections can also be classified based on their severity, the presence of comorbidities, and the need and nature of therapeutic intervention:

\section{CLASS 1}

Noncomplicated infection with no systemic signs or symptoms indicating spread of infection, such as fever, tachycardia, vomiting, severe fatigue, edema, and with no uncontrolled comorbidities that may complicate treatment. Outpatient management with topical or oral antimicrobials is recommended.

\section{CLASS 2}

Infection with systemic signs or symptoms or with stable comorbidities, or infection without signs of systemic infection but with uncontrolled comorbidities. This form may require hospitalization or outpatient parenteral antibiotics administration

\section{CLASS 3}

Infection with systemic signs or symptoms or uncontrolled comorbidities. Inpatient management with parenteral antibiotics is required.

\section{CLASS 4}

Infection with signs of sepsis (tachycardia, tachypnea, hypotension, mental status changes); inpatient management (possibly at a critical care unit) with parenteral antibiotics is required. In some cases, surgery may be indicated $(6,8)$.

\section{RISK FACTORS}

Risk factors for skin and subcutaneous tissue infections include decreased blood supply and tissue oxygenation, increased peripheral fluid retention, skin trauma, and decreased ability to fight infections $(7,9)$.

The main risk factors include:

- Age (elderly and young children)

- Alcohol abuse (increased risk of necrotizing soft tissue infections)

- Anatomical or functional asplenia

- Chronic cardiovascular and respiratory diseases
- powierzchowne ropnie

- zakażenia związane z urazem

\section{Powiklane}

- głębokie rozległe ropnie

- martwicze zapalenie powięzi

- zgorzel gazowa

- zgorzel Fouriera

- zakażenia będące wynikiem pogryzienia przez zwierzęta lub człowieka

\section{W zależności od przebiegu}

- lekkie

- umiarkowane

- ciężkie

Zakażenia skóry i tkanek miękkich można klasyfikować także w oparciu o ich nasilenie, obecność chorób współistniejących oraz potrzebę i charakter interwencji terapeutycznej:

\section{STOPIEŃ 1}

Niepowikłana infekcja bez objawów ogólnoustrojowych takich, jak gorączka, tachykardia, wymioty, znaczne osłabienie, obrzęki, wskazujących na rozprzestrzenianie się zakażenia oraz bez niekontrolowanych chorób współistniejących, które mogą utrudniać leczenie. Zalecane leczenie ambulatoryjnego z zastosowaniem miejscowych lub doustnych środków przeciwdrobnoustrojowych

\section{STOPIEŃ 2}

Zakażenie z objawami ogólnoustrojowymi lub z towarzyszącymi stabilnymi chorobami współistniejącymi lub zakażenie bez cech ogólnoustrojowego zakażenia, ale z niekontrolowanymi chorobami współistniejącymi. Ta postać może wymagać leczenia szpitalnego lub podawania antybiotyków pozajelitowych w warunkach ambulatoryjnych.

\section{STOPIEŃ 3}

Zakażenie z objawami systemowymi lub niekontrolowanymi chorobami współistniejącymi. Wymagane leczenie w trybie stacjonarnym za pomocą antybiotyków podawanych pozajelitowo.

\section{STOPIEŃ 4}

Zakażenie z objawami posocznicy (tachykardia, tachypnoe, hypotensja, zaburzenia świadomości), konieczne leczenie w warunkach szpitalnych (z uwzględnieniem hospitalizacji w oddziale intensywnej terapii) z zastosowania antybiotyków podawanych pozajelitowo. W niektórych przypadkach należy uwzględnić konieczność leczenia operacyjnego $(6,8)$. 
- Diabetes mellitus (risk of necrotizing soft tissue infections and hospital-acquired MRSA infections)

- Dialysis (hospital-acquired MRSA)

- Liver cirrhosis

- Immunesupresion (congenital or acquired, HIV infection, cancer, iatrogenic)

- Human or animal bite wounds

- Lymphoedema or lymphatic insufficiency

- Obesity

- Peripheral arterialvenous insufficiency

- Peripheral neuropathy

- Drug abuse

- Longterm vascular access (hospital-acquired MRSA infections)

- Prolonged hospitalization (hospital-acquired MRSA infections)

- Occupational exposure of medical staff

- Malnutrition (increased risk of necrotizing soft tissue infections),

- Profession, e.g. soldiers (community-acquired MRSA infections)

- Athletes (community-acquired MRSA infections)

- Patients in longterm care facilities (hospital-acquired MRSA infections)

- Swimming pools, hydromassage baths, sea water increased risk of waterborne infections) $(6,7,10)$

\section{AETIOLOGICAL FACTORS FOR SKIN AND SOFT TISSUE INFECTIONS}

1. Abscesses:

- Staphylococcus aureus

- Streptococcus spp.

- anaerobes

2. Human or animal bites (multifactorial aetiology)

- Bacteroides spp.

- Bartonella henselae

- Capnocytophaga canimorsus

- Eikenella corrodens

- Pasteurella multocida

- Peptostreptococcus

- S. aureus

- Streptobacillus moniliformis

3. Gas gangrene

- Clostridium perfringens

- Clostridium septicum

4. Erysipelas, superficial cellulitis

- $\beta$-haemolytic streptococci (predominantly Group A)

- S. aureus

5. Folliculitis

- Candida spp.

- dermatophytes

- Pseudomonas aeruginosa

- S. aureus

\section{CZYNNIKI RYZYKA}

Do zakażeń skóry i tkanek podskórnych usposabia pogorszenie ukrwienia i utlenowania tkanek, zwiększenie zastoju płynu obwodowego, uraz skóry oraz zmniejszona zdolność do zwalczania infekcji $(7,9)$.

Do głównych czynników ryzyka należą:

- Wiek (osoby starsze i małe dzieci)

- Alkoholizm (zwiększone ryzyko martwiczych zakażeń tkanki łącznej)

- Asplenia anatomiczna lub czynnościowa

- Przewlekłe choroby układu sercowo-naczyniowego i układu oddechowego

- Cukrzyca (ryzyko martwiczych zakażeń tkanki łącznej i zakażeń wywołanych przez szpitalne szczepy MRSA)

- Dializoterapia (szpitalne szczepy MRSA)

- Marskość wątroby

- Immunosupresja (wrodzona i nabyta, zakażenie HIV, nowotworowy, jatrogenna)

- Rany kąsane zadane przez ludzi lub zwierzęta

- Obrzęk limfatyczny lub niewydolność limfatyczna

- Otyłość

- Obwodowa niewydolność tętniczo-żylna

- Neuropatia obwodowa

- Narkomania

- Długotrwały dostęp naczyniowy (zakażenia szpitalnymi szczepami MRSA)

- Przedłużona hospitalizacja (zakażenia szpitalnymi szczepami MRSA)

- Narażenie zawodowe u pracowników medycznych

- Niedożywienie (zwiększone ryzyko martwiczych zakażeń tkanki łącznej)

- Zawód np. żołnierze (zakażenia pozaszpitalnymi szczepami MRSA)

- Sportowcy (zakażenia pozaszpitalnymi szczepami MRSA)

- Pacjenci domów opieki długoterminowej (szpitalne szczepy MRSA)

- Baseny, wanny z hydromasażem, woda morska zwiększone ryzyko zakażeń wodnopochodnych) $(6,7,10)$.

\section{CZYNNIKI ETIOLOGICZNE ZAKAŻEŃ SKÓRY I TKANEK MIĘKKICH}

1. Ropnie:
- Staphylococcus aureus
- Streptococcus spp.
- beztlenowce

2. Pogryzienia przez człowieka lub zwierzęta (etiologia wieloczynnikowa)

- Bacteroides spp.

- Bartonella henselae

- Capnocytophaga canimorsus 
6. Fournier gangrene

- multifactorial

7. furuncle; furunculosis

- S. aureus

8. Impetigo

- $\beta$-haemolytic streptococci (predominantly Group A)

- S. aureus

9. Necrotizing fasciitis

Type I - mixed infection (S. pyogenes, S. aureus, Enterococcus spp., E. coli, Klebsiella spp., Pseudomonas aeruginosa, Enterobacter spp., Proteus spp. Bacteroides spp., Clostridium spp.

Type II - monobacterial infection - Streptococcus pyogenes $(6,7,11)$.

Comorbidities and/or mechanisms of skin injury affect the aetiological agent types, which facilitates appropriate selection of antibiotic therapy. For example, skin and soft tissue infections caused by Pseudomonas aeruginosa are often associated with intravenous drug abuse, but also with excessive hot tub baths. Neutropenic patients are prone to infections caused by Gram-negative bacteria, anaerobes, or fungi (6).

Staphylococci and streptococci are responsible for most simple comminity-acquired skin and soft tissue infections. An analysis by GJ. Moet showed that $\beta$-haemolytic streptococci caused almost $3 / 4$ cases of necrotizing cellulitis, with $S$. aureus, Pseudomonas aeruginosa, Enterococcus spp., and E. coli being the predominant factors for hospital-acquired skin and subcutaneous tissue infections $(12,13)$.

\section{CLINICAL PRESENTATION.}

Clinical presentation depends on the type of skin and soft tissue infection; however, local symptoms including redness, warmth, swelling and pain at the infection site are the main complaints. Superficial infections such as erysipelas or cellulitis are characterized by induration at the infection site $(6,7,10)$.

Necrotizing cellulitis is characterized primarily by the rapid progression of the infection, the occurrence of hemorrhagic or bullous skin lesions, no or decreased sensation, and crepitation consistent with the presence of gas in the soft tissues. Prominent swelling and vesicles help differentiate between necrotizing and nonnecrotizing infections (14). Local symptoms may accompany systemic symptoms such as fever, marked weakness, general malaise, tachycardia, hypotension, impaired consciousness (confusion) (6,7). The severity of systemic symptoms reflects the severity of the infection and may indicate rapid spread of the infection and risk of sepsis development. Infections of the lower limbs in patients with diabetes mellitus, head
- Eikenella corrodens

- Pasteurella multocida

- Peptostreptococcus

- S. aureus

- Streptobacillus moniliformis

3. Zgorzel gazowa

- Clostridium perfringens

- Clostridium septicum

4. Róża, powierzchowne zapalenie tkanki łącznej

- paciorkowce $\beta$-hemolizujące (głównie grupa A)

- S. aureus

5. Zapalenie mieszków włosowych

- Candida spp.

- dermatofity

- Pseudomonas aeruginosa

- S.aureus

6. Zgorzel Fouriera

- wieloczynnikowa

7. czyrak; czyraczność

- S.aureus

8. Liszajec

- paciorkowce $\beta$-hemolizujące (głównie grupa A)

- S. aureus

9. Martwicze zapalenie powięzi

Typ I - zakażenie mieszane (S.pyogenes, S.aureus, Enterococcus spp., E.coli, Klebsiella spp., Pseudomonas aeruginosa, Enterobacter spp., Proteus spp. Bacteroides spp., Clostridium spp.

Typ II - zakażenie o etiologii monobakteryjnej Streptococcus pyogenes $(6,7,11)$.

Choroby wspótistniejące i/lub mechanizmy uszkodzenia skóry mają wpływ na rodzaj czynnika etiologicznego, co ułatwia właściwy dobór antybiotykoterapii. Przykładowo zakażenia skóry i tkanek miękkich wywołane przez Pseudomonas aeruginosa są często związane $\mathrm{z}$ dożylną narkomanią, ale także $\mathrm{z}$ nadużywaniem gorącej kąpieli w wannie. Pacjenci z neutropenią są narażeni na infekcje bakterii Gram-ujemnych, beztlenowców lub grzybów (6).

Gronkowce i paciorkowce są odpowiedzialne za większość niepowikłanych pozaszpitalnych zakażeń skóry i tkanek miękkich. W analizie przeprowadzonej przez GJ Moet stwierdzono, że paciorkowce $\beta$-hemolizujące powodują prawie $3 / 4$ przypadków martwiczego zapalenia tkanki łącznej, a dominującymi czynnikami zakażeń skóry i tkanki podskórnej nabytych w szpitalu są $S$. aureus, Pseudomonas aeruginosa, Enterococcus spp. oraz E. coli $(12,13)$.

\section{OBRAZ KLINICZNY}

Obraz kliniczny zależy od rodzaju zakażenia skóry i tkanek miękkich, jednak głównymi są objawy miejscowe takie jak zaczerwienienie, zwiększone ucieplenie, obrzęk i ból w miejscu zakażenia. W zakażeniach 
infections, necrotizing infections and severe hospitalacquired infections are associated with a higher risk of mortality (11).

\section{DIAGNOSIS}

The diagnosis of skin and soft tissue infections based on the clinical picture.

It is useful to determine inflammatory markers, which also allow to assess the severity of infection. Creactive protein (CRP), complete peripheral blood count with differential leucocyte count, creatinine, glucose, sodium, and potassium tests are indicated. In case of severe course, investigations should also include procalcitonin testing, coagulation tests (APTT, PT), liver function tests (transaminases, bilirubin) $(6,7,10)$. Table I shows parameters that help to assess the risk of necrotizing fasciitis $(6,15)$.

Table I. Risk indicator for necrotizing fasciitis (15)

Tabela I. Wskaźnik ryzyka martwiczego zapalenia powięzi (15)

\begin{tabular}{|l|c|}
\hline \multicolumn{1}{|c|}{ Laboratory variable } & Score \\
\hline CRP: & \\
$<150 \mathrm{mg} / 1$ & 0 \\
$\geq 150 \mathrm{mg} / 1$ & 4 \\
\hline Creatinine: & \\
$\leq 141 \mu \mathrm{mol} / 1$ & 0 \\
$>141 \mu \mathrm{mol} / 1$ & 2 \\
\hline Glucose: & \\
$\leq 10 \mathrm{mmol} / 1$ & 0 \\
$>10 \mathrm{mmol} / 1$ & 1 \\
\hline Haemoglobin: & \\
$>13.5 \mathrm{~g} / \mathrm{dl}$ & 0 \\
$11-13.5 \mathrm{~g} / \mathrm{dl}$ & 1 \\
$<11 \mathrm{~g} / \mathrm{dl}$ & 2 \\
\hline $\begin{array}{l}\text { Sodium: } \\
\geq 135 \mathrm{mmol} / 1\end{array}$ & 0 \\
$<135 \mathrm{mmol} / 1$ & 2 \\
\hline $\begin{array}{l}\text { White blood cell count: } \\
<15 \mathrm{x} 109 / 1\end{array}$ & 0 \\
$15-25 \mathrm{x} 109 / 1$ & 1 \\
$>25 \times 109 / 1$ & 2 \\
\hline $\begin{array}{l}\text { Maximum score: } 13 \text { points. Score of } 6 \text { or more may } \\
\text { indicate necrotizing fasciitis, and scores } 8 \text { or higher are } \\
\text { highly predictive }\end{array}$ \\
\hline
\end{tabular}

Imaging diagnostics (Xray, ultrasound, computed tomography, magnetic resonance imaging) is not necessary in simple infections, but it may be helpful in the case of necrotizing fasciitis, or deep abscesses. Radiologic investigation should not delay the surgical treatment $(6,7,10)$.

In the case of uncomplicated skin and soft tissue infections in otherwise healthy patients without comorbidities, microbiological diagnostics is powierzchownych, takich jak róża czy cellulitis charakterystyczne jest stwardnienie $\mathrm{w}$ miejscu infekcji $(6,7,10)$.

Martwicze zapalenia tkanki łącznej charakteryzują się przede wszystkim szybkim postępem zakażenia, występowaniem skórnych zmian krwotocznych lub pęcherzowych, zniesieniem lub osłabieniem czucia oraz trzeszczeniem wskazującym na obecność gazu w tkankach miękkich. Wyraźny obrzęk i pęcherze pomagają odróżnić zakażenie martwicze od nie martwiczego (14). Objawom miejscowym mogą towarzysząc objawy ogólnoustrojowe, jak gorączka, znaczne osłabienie, uczucie ogólnego rozbicia, tachykardia, hypotensja, zaburzenia świadomości (splątanie) $(6,7)$. Intensywność objawów ogólnoustrojowych odzwierciedla ciężkość zakażenia i może wskazywać na szybkie szerzenie się zakażenia prowadzące do posocznicy włącznie. Zakażenia w zakresie kończyn dolnych u pacjentów z cukrzycą, zakażenia w obrębie głowy, zakażenia martwicze oraz ciężkie zakażenia szpitalne stwarzają większe ryzyko śmiertelności (11).

\section{ROZPOZNANIE}

Podstawą rozpoznania zakażeń skóry i tkanek miękkich jest obraz kliniczny.

$\mathrm{W}$ diagnostyce pomocne jest oznaczenie markerów stanu zapalnego, pozwalających również na ocenę ciężkości zakażenia. Wskazane jest oznaczenie: białka C-reaktywnego (CRP), morfologii krwi obwodowej z leukocytogramem, kreatyniny, glukozy, sodu, potasu. W przypadku ciężkiego przebiegu należy poszerzyć badania o oznaczenie prokalcytoniny, wskaźników krzepnięcia (APTT, PT), parametrów oceniających funkcję wątroby (aminotransferazy, bilirubina) $(6,7,10)$. W Tabeli I przedstawiono parametry pomocne w ocenie ryzyka martwiczego zapalenia powięzi $(6,15)$.

Diagnostyka obrazowa (RTG, ultrasonografia, tomografia komputerowa, rezonans magnetyczny) nie jest konieczna w niepowikłanych zakażeniach, natomiast może być pomocna $\mathrm{w}$ diagnostyce martwiczego zakażenia mięśni i powięzi, czy ropni głębokich. Badania obrazowe nie powinny opóźniać opracowania chirurgicznego $(6,7,10)$.

W przypadku niepowikłanych zakażeń skóry i tkanek miękkich u pacjentów zdrowych i bez chorób wspólistniejących, diagnostyka mikrobiologiczna jest zbędna. Natomiast diagnostykę mikrobiologiczną należy rozważyć u pacjentów z:

- ciężkimi zakażeniami i towarzyszącymi objawami ogólnoustrojowymi

- obniżoną odpornością

- zakażeniem wymagającym opracowania chirurgicznego 
unnecessary. However, microbiological diagnostics should be considered in patients with:

- serious infections and associated systemic symptoms

- impaired immunity

- infection requiring surgical treatment

- sepsis

- recurrent, persistent or large abscesses

- extensive cellulitis and lymphangitis

- infections following animal or human bites

- hospitalacquired infections

- no improvement after the first treatment $(6,7,10)$.

Tissue biopsy or sterile aspiration of infected tissue, preferably collected prior to initiation of antibiotic therapy, are the most valuable materials for microbiological testing. In case of infections suspected of bacteraemia, blood cultures should be performed. However, swabs taken from surface of inflametaed skin have no diagnostic quality $(6,7,16,17)$.

\section{PRINCIPLES OF MANAGEMENT AND TREATMENT}

Management depends on the presentation, severity and location of infection and comorbidities (Fig. 1, 2 and 3) $(6,7,10)$.

Uncomplicated infections limited to the skin and soft tissues located just below the skin can be effectively treated in outpationts clinic with oral antibiotics. These antibiotics should cover Staphylococcus and Streptococcus.

If, after two days of optimal antimicrobial treatment, there is no improvement or a worsening is observed. An antibiotic covering methicillin-resistant $S$. aureus should be used $(6,7)$.

In case of superficial and/or small abscesses, management involves incision and drainage, followed by local treatment. Antibiotic therapy is required for abscesses:

- associated with extensive cellulitis

- with rapid progression or poor response to drainage

- located on the face, head, hands, genitals

- in children and the elderly

- in patients with comorbidities or immunosuppression $(7,18)$

Serious infections with suspected necrotizing fasciitis, including infections with uncontrolled comorbidities, or in immunocompromised patients, require empiric broad-spectrum antibiotic therapy, inpatient treatment, and possibly surgical treatment. After microbiological confirmation of the aetiological agent with drug susceptibility assessment, broadspectrum antibiotic therapy may be switched to targeted therapy.

\section{- posocznicą}

- nawracającymi, uporczywymi lub dużymi ropniami

- rozległym zapaleniem tkanki łącznej i zapaleniem naczyń limfatycznych

- zakażeniami po ugryzieniach przez zwierzęta lub ludzi

- zakażeniami nabytymi w trakcie pobytu w szpitalu

- brakiem poprawy po pierwszym schemacie leczenia $(6,7,10)$.

Najwartościowszym materiałem do badania mikrobiologicznego są biopsje tkankowe lub sterylna aspiracja zakażonej tkanki, najlepiej pobrane przed rozpoczęciem antybiotykoterapii. W przypadku zakażeń z podejrzeniem bakteriemii należy wykonać posiewy krwi. Natomiast powierzchowne wymazy ze zmienionej zapalenie skóry nie mają waloru diagnostycznego $(6,7,16,17)$.

\section{ZASADY POSTEPOWANIA I LECZENIA}

Postępowanie zależy od postaci, ciężkości i lokalizacji zakażenie oraz chorób współistniejących (Ryc. 1, 2 i 3$)(6,7,10)$.

Zakażenia niepowikłane, ograniczone do skóry i znajdującej się tuż pod skórą tkanki miękkiej u osób bez istotnych obciążeń mogą być skutecznie leczone antybiotykami doustnymi w warunkach ambulatoryjnych. Antybiotyki te powinny obejmować swym spektrum bakterie z rodzaju Staphylococcus oraz Streptococcus.

Jeśli mimo prawidłowo prowadzonego leczenia przeciwdrobnoustrojowego przez dwie doby brak jest poprawy lub następuje pogorszenie, konieczne jest zastosowanie antybiotyku obejmujący swym spektrum szczepy metycylinooporne $S$. aureus $(6,7)$.

$\mathrm{W}$ przypadku powierzchownych i/lub małych ropni postępowanie sprowadza się do nacięcia i drenażu oraz leczenia miejscowego. Antybiotykoterapia jest wymagana $\mathrm{w}$ przypadku ropni:

- związanych z rozległym zapaleniem tkanki łącznej

- z szybkim postępem lub słabą odpowiedzią na drenaż

- zlokalizowanych na twarzy, głowie, dłoniach, okolicy narządów płciowych

- u dzieci i osób starszych

- u osób z chorobami współistniejącymi lub z immunosupresją $(7,18)$.

Ciężkie zakażenia $\mathrm{z}$ podejrzeniem martwiczego zapalenia powięzi włącznie, zakażenie z niekontrolowanymi chorobami współistniejącymi lub u chorych z obniżoną odpornością wymagają empirycznej szerokospektralnej antybiotykoterapii, leczenia szpitalnego oraz rozważenia leczenia chirurgicznego. Po mikrobiologicznym potwierdzeniu czynnika etiologicznego z oceną jego lekowrażliwości, antybiotykoterapię sze- 
Fig. 1. Therapeutic algorithm for patients with skin and soft tissue infection (6)

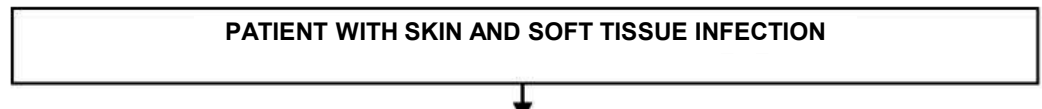

Is the infection severe or complicated (progressing) despite outpatient antibiotic therapy or drainage?

Does the patient have symptoms of sepsis or immunosuppression?

Does the patient have any uncontrolled concomitant diseases?

Is the patient intolerant to oral antibiotic therapy?

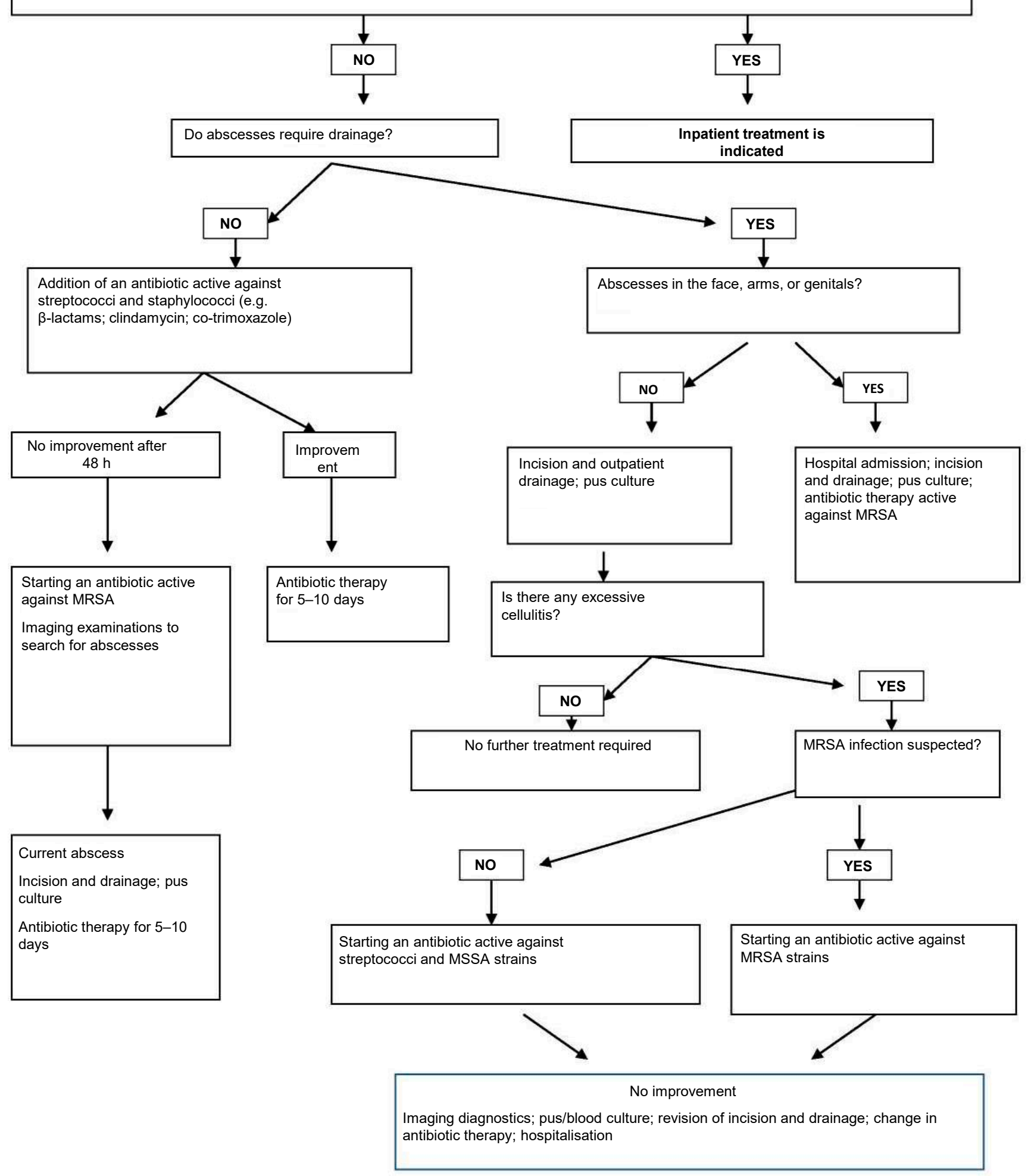


Ryc.1. Algorytm postępowania z pacjentem z zakażeniem skóry i tkanek miękkich (6)

\section{PACJENT Z ZAKAŻENIEM SKÓRY I TKANEK MIĘKKICH}

Czy ciężkie lub powikłane (progresja) zakażenie pomimo ambulatoryjnej antybiotykoterapii lub drenażu?

Czy pacjent $z$ objawami posocznicy lub $w$ immunosupresji?

Czy pacjent ma niekontrolowane choroby współistniejace?

Czy pacjent nie toleruje doustnej antybiotykoterapii?

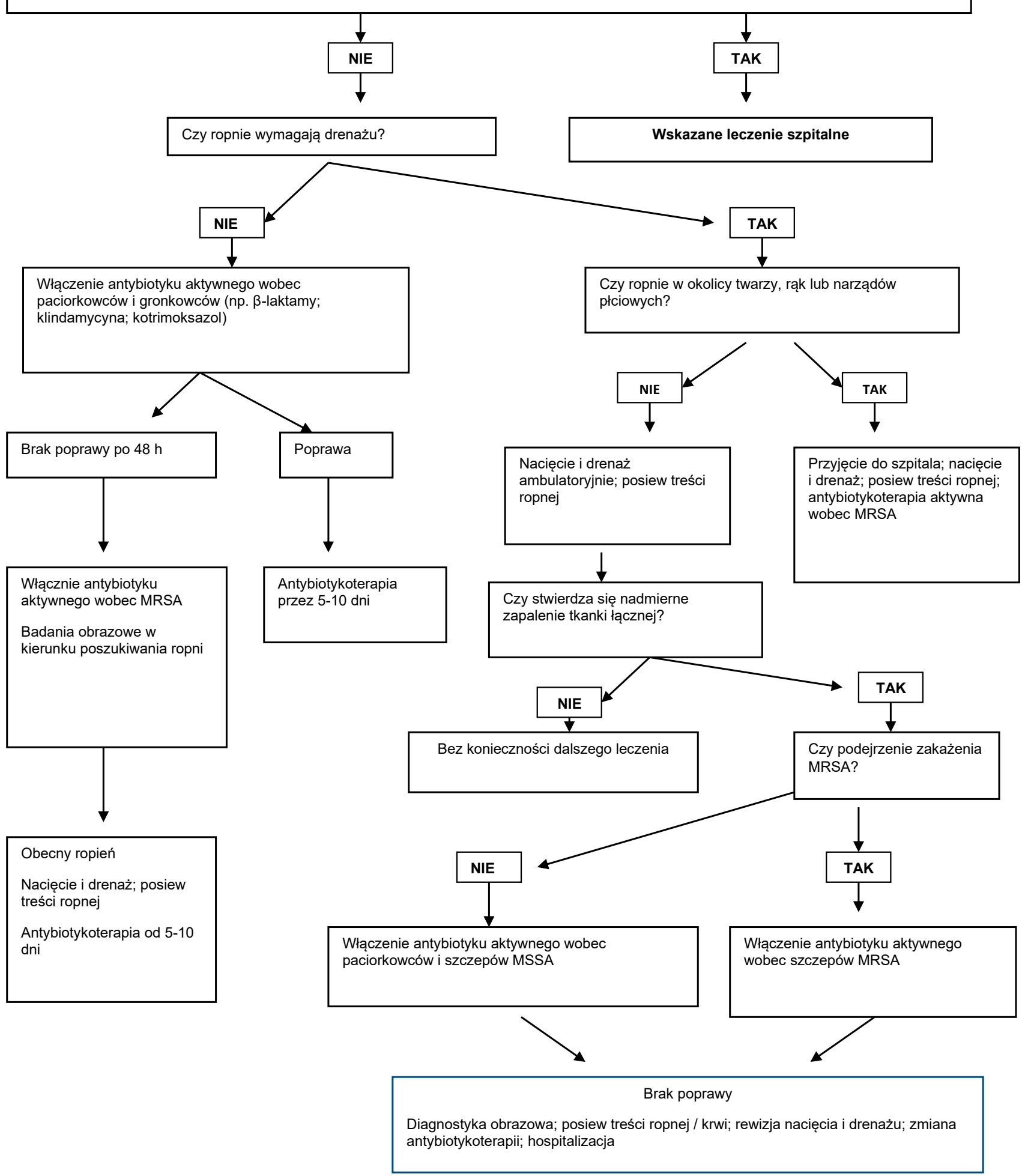


Fig. 2. Algorithm for inpatient management of patients with skin and soft tissue infection (6)
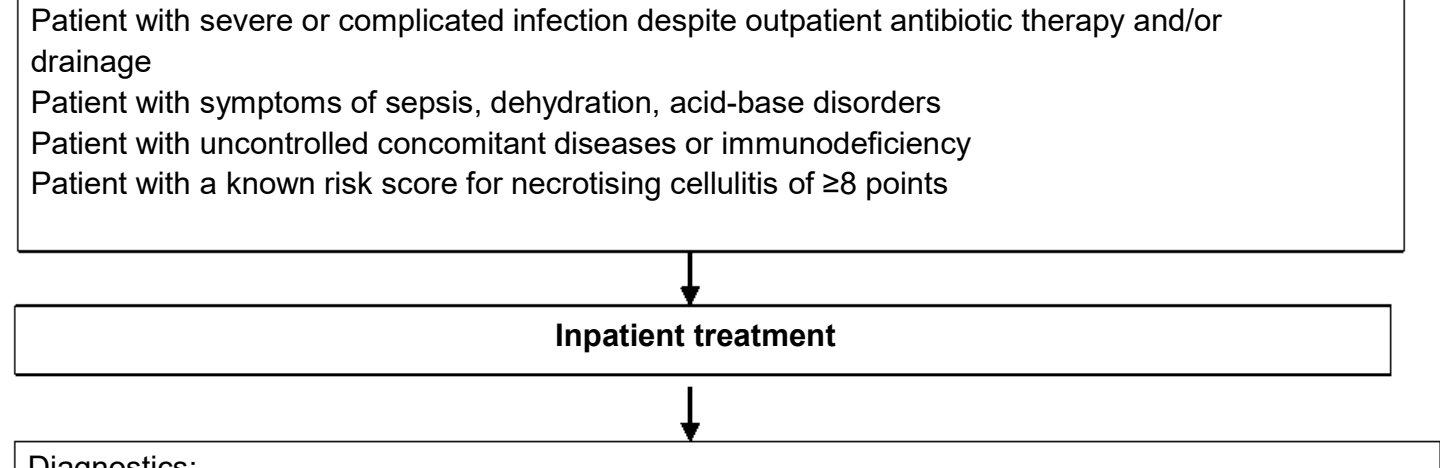

Diagnostics:

CBC with differential, CRP, renal and liver function tests

Blood culture in patients with severe infection, immunodeficiency, in the elderly

Aspiration biopsy or purulent material from abscesses or subcutaneous fluid collections

Imaging diagnostics for necrotising fasciitis only if it does not delay treatment

Marginal cellulitis biopsy after debridement in patients with necrotising fasciitis or bites

Correction of water and electrolyte and acid-base abnormalities

Empiric broad-spectrum antibiotic therapy active against MRSA strains

Targeted antibiotic therapy based on sensitivity testing for 7-14 days.

Switch to oral treatment after clinical improvement and with good tolerability of oral antibiotic therapy
Is surgical consultation indicated? Suspected deep abscess, necrotising fasciitis, gas gangrene or deep biting penetrating to the joint?

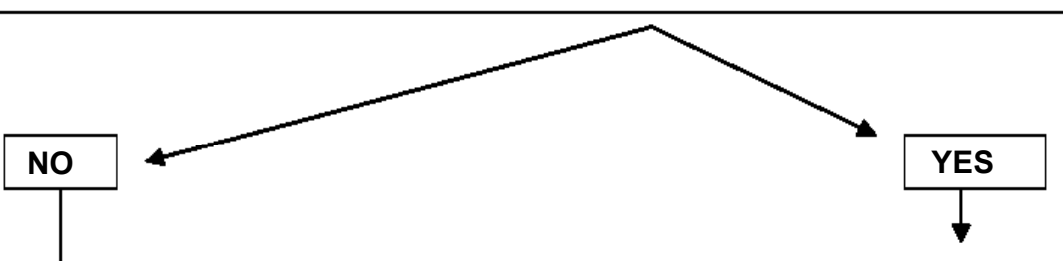

Abscess: incision and drainage, continuation of antibiotic therapy active against MRSA

Necrotising fasciitis: surgical treatment and continuation of wide-spectrum antibiotic therapy

Bites; gas gangrene: surgical treatment and continuation of antibiotic therapy

Switch to oral treatment after clinical improvement, with good tolerability of oral antibiotic therapy and after the completion of surgical treatment (debridement / drainage)

Total treatment period of 7-14 days or 6 weeks in case of joint involvement 
Ryc. 2. Algorytm szpitalnego postępowania z pacjentem z zakażeniem skóry i tkanek miękkich (6)

Pacjent z ciężkim lub powikłanym przebiegiem zakażenia pomimo ambulatoryjnej antybiotykoterapii i/lub drenażu

Pacjent z objawami posocznicy, odwodnienia, zaburzeń kwasowo-zasadowych

Pacjent z niekontrolowanymi chorobami współistniejącymi lub z zaburzeniami odporności

Pacjent, u którego stwierdzono wskaźnik ryzyka martwiczego zapalenia tkanki łącznej $\geq 8$ pkt

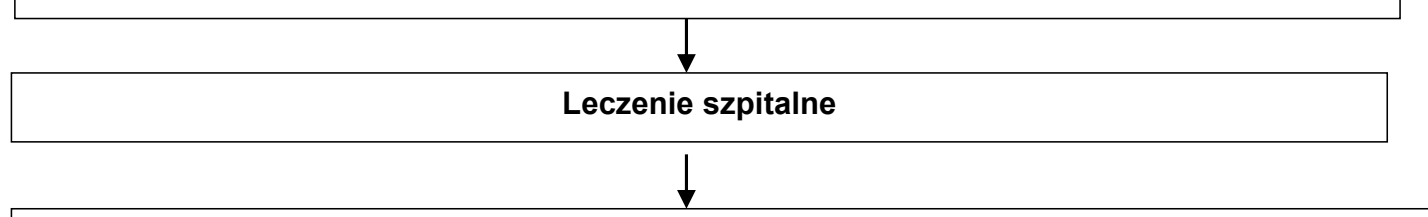

Diagnostyka:

Morfologia z rozmazem, CRP, parametry oceniające funkcję nerek i wątroby

Posiew krwi u pacjentów: z ciężkim przebiegiem zakażenia; w immunosupresji; starszych

Biopsja aspiracyjnego materiału ropnego z ropni lub podskórnych przestrzeni płynowych

Diagnostyka obrazowa w kierunku martwiczego zapalenia powięzi, tylko jeżeli to nie opóźni leczenia

Biopsja z pogranicza zapalenia tkanki łącznej po oczyszczeniu u pacjentów z martwiczym zapaleniem powięzi lub po pogryzieniach

Wyrównanie zaburzeń wodno-elektrolitowych i kwasowo-zasadowych

Empiryczna szerokospektralna antybiotykoterapii z uwzględnieniem szczepów MRSA

Czy wskazana konsultacja chirurgiczna? Czy podejrzenie głębokiego ropnia, martwiczego zapalenia powięzi, zgorzeli gazowej lub głębokiego ugryzienia penetrującego do stawu?

Celowana antybiotykoterapia zgodnie $z$ wynikiem antybiogramu przez 7-1 4 dni. Zmiana na leczenie doustne po poprawie klinicznej oraz dobrej tolerancji antybiotykoterapii doustnej

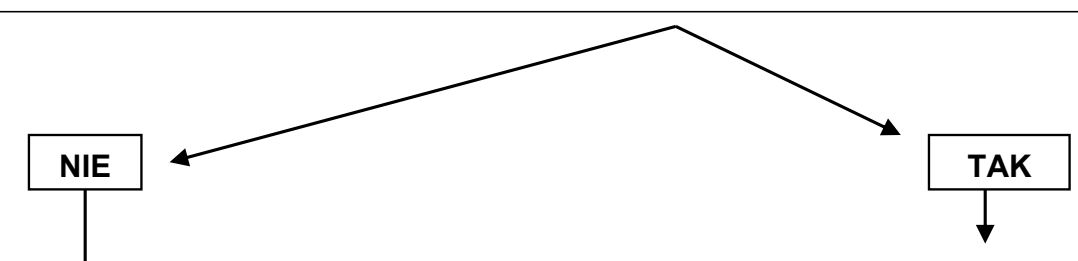

Ropień: nacięcie i drenaż, kontynuacja antybiotykoterapii aktywnej wobec MRSA

Martwicze zapalenie powięzi: chirurgiczne opracowanie i kontynuacja szerokospektralnej antybiotykoterapii

Ugryzienia; zgorzel gazowa: chirurgiczne opracowanie i kontynuacja antybiotykoterapii

Zmiana na leczenie doustne po poprawie klinicznej, przy dobrej tolerancji antybiotykoterapii doustnej oraz po zakończeniu leczenia chirurgicznego (oczyszczenie / drenaż)

Całkowity okres leczenia od 7-1 4 dni lub 6 tygodni w przypadku zajęcia stawu 
Fig. 3. Therapeutic algorithm for bacterial infections of the skin and soft tissues (7)

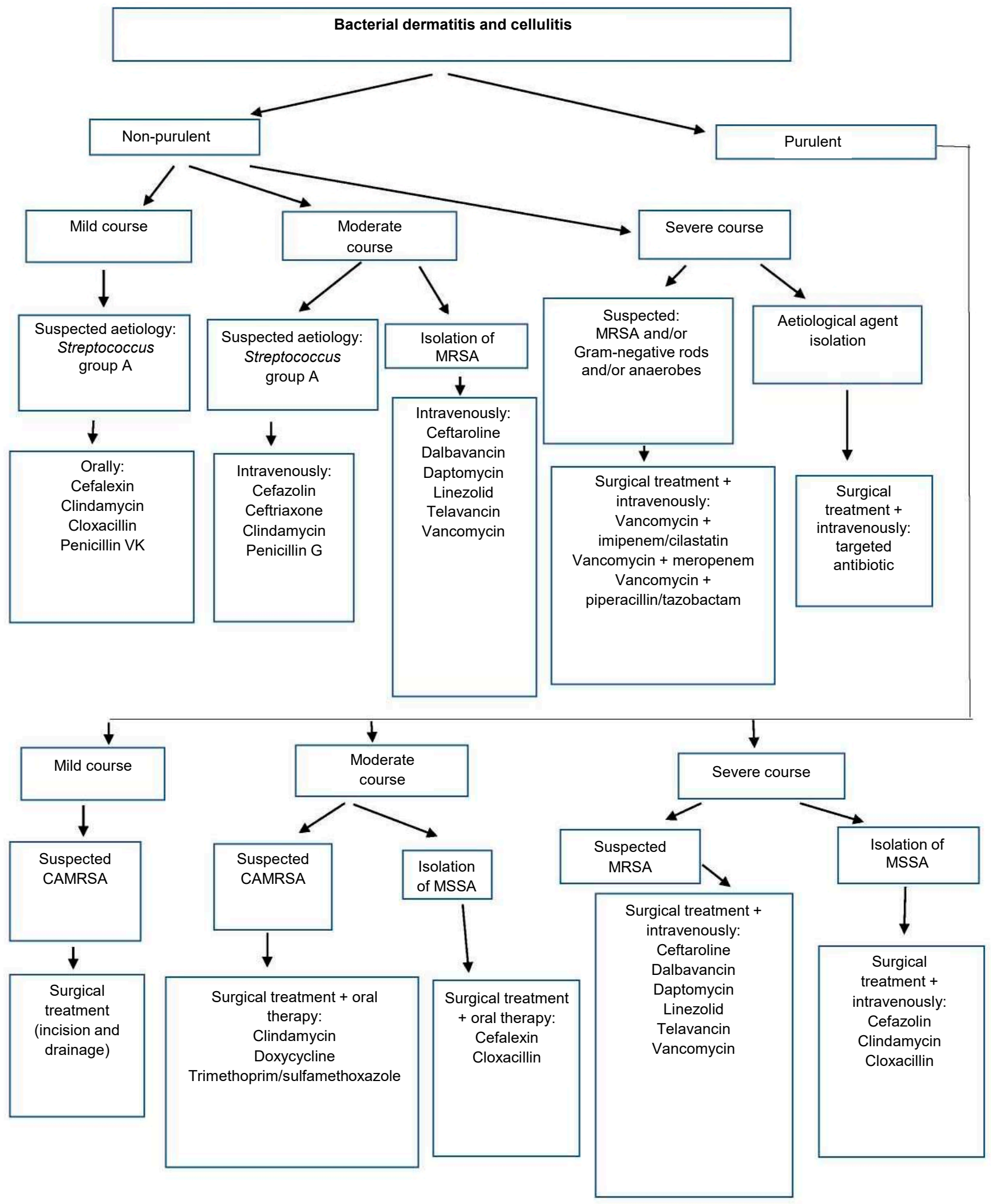


Ryc. 3. Algorytm leczenia bakteryjnych zakażeń skóry i tkanek miękkich (7)

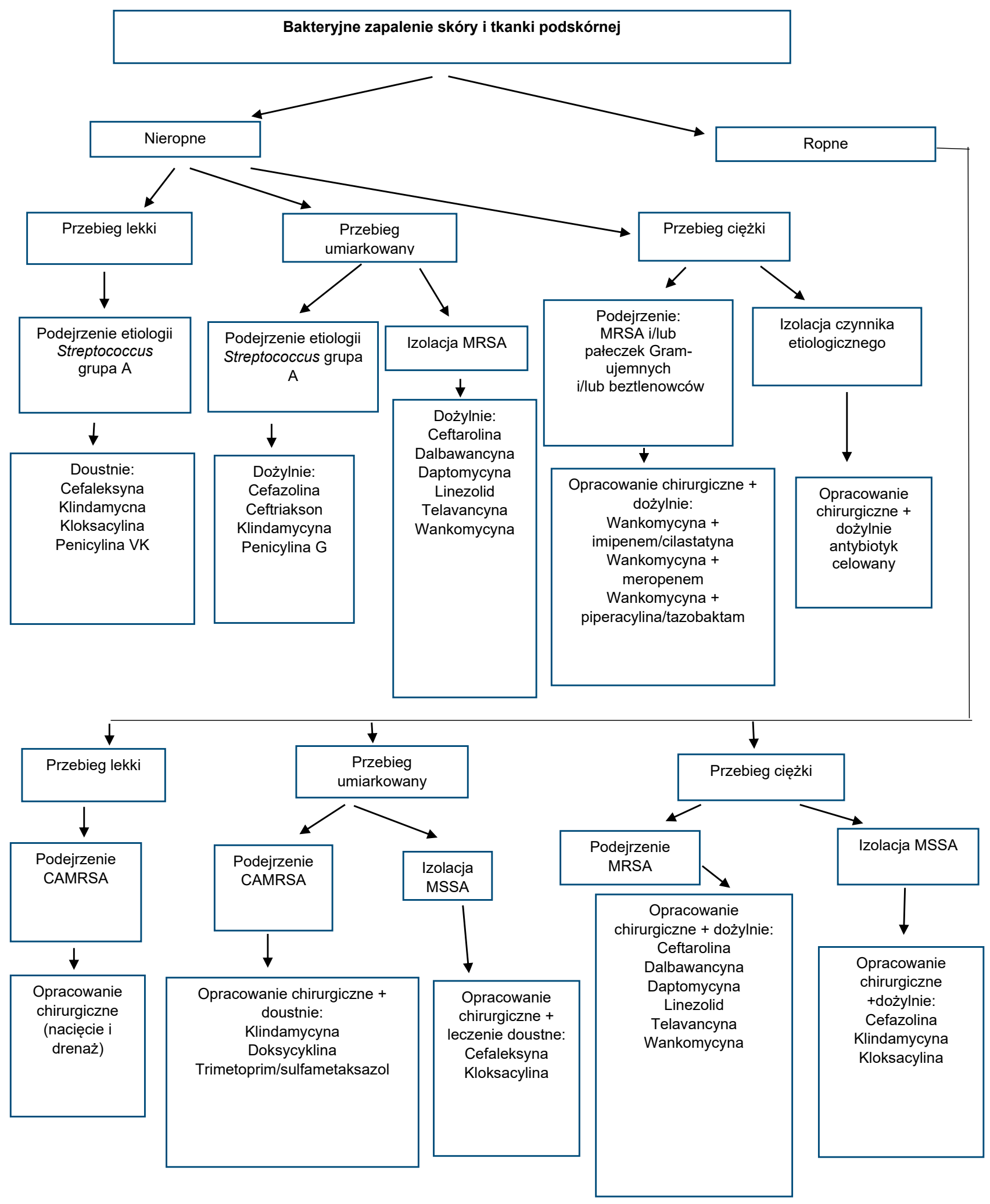


Hospitalization is necessary in patients with:

- severe or complicated infections

- signs or symptoms of sepsis

- unstable comorbidities

- need for surgical treatment under anesthesia

- lack of response despite appropriate outpatient antibiotic therapy

- intolerance to oral antibiotics $(6,7)$.

Early diagnosis, prompt surgical treatment, and the use of broad-spectrum antibiotic therapy covering MRSA strains are of key importance in the management of necrotizing fasciitis (7).

A special group are immunocompromised patients, due to greater susceptibility to skin and soft tissue infections, often nonspecific clinical presentation associated with a weakened inflammatory response. Antimicrobial therapy in this patient group should take into account less common aetiological factors such as multi-drug resistant Gram-negaive bacteria (e.g. Pseudomonas aeruginosa, Acinetobacter baumanii), anaerobes, fungi (7).

A specific type of infection are infections caused by animal or human bites. These infections can be severe or complicated, which is associated with a particular microflora of the mouth, especially in animals. In these cases, antimicrobial therapy is necessary, particularly in immunocompromised patients, facial or hand wounds, periosteal or joint capsule damage. The treatment of choice are $\beta$-lactam antibiotics in combination with $\beta$-lactamase inhibitors. In case of allergy to penicillin, trimethoprim/sulfamethoxazole, or a fluoroquinolone in combination with clindamycin or metronidazole can be used. In addition, in this group of infections, the indications for post-exposure tetanus and rabies prophylaxis should always be evaluated $(7,19)$.

Empiric therapy for uncomplicated waterborne skin and soft tissue infections includes fluoroquinolones, and doxycycline should be used following exposure to saltwater (7).

Antimicrobial therapy in hospitalized patients takes 7 to 14 days to complete. Intravenous antibiotic therapy should only be replaced by oral antibiotic therapy after achieving clinical improvement, completing surgical treatment, and confirming good tolerability of oral treatment. In outpatient treatment of uncomplicated skin and soft tissue infections, the duration of antibiotic therapy ranges from 5 to 10 days $(6,7,10)$.

One important problem in patients with skin and subcutaneous tissue infection is the risk of relapse. This phenomenon is observed in the case of furuncles, erysipelas, or superficial cellulitis (Table II) (10).

Therefore, prophylaxis with oral penicillin $250 \mathrm{mg}$ BID for 6 months is recommended in patients with at least one prior episode of cellulitis. This prophylaxis rokospekralaną można zastąpić leczeniem celowanym. Leczenie $\mathrm{w}$ warunkach szpitalnych jest koniczne u pacjentów $\mathrm{z}$ :

- ciężkimi lub powikłanymi zakażeniami

- objawami posocznicy

- niestabilnymi chorobami współistniejącymi

- koniecznością opracowania chirurgicznego w znieczuleniu

- brakiem odpowiedzi pomimo odpowiedniej ambulatoryjnej antybiotykoterapii

- nietolerancją doustnych antybiotyków $(6,7)$.

W leczeniu martwiczego zapalenia powięzi kluczowe znaczenia ma wczesne rozpoznanie, szybkie opracowanie chirurgiczne oraz zastosowanie antybiotykoterapii szerokospektralnej z uwzględnieniem szczepów MRSA (7).

Szczególną grupę stanowią pacjenci z obniżoną odpornością, z uwagi na większą podatność na zakażenia skóry i tkanek miękkich, często niecharakterystyczny obraz kliniczny związany z osłabioną odpowiedzią zapalną. Terapia przeciwdrobnoustrojowa $\mathrm{w}$ tej grupie pacjentów powinna uwzględnić rzadsze czynniki etiologiczne takie, jak wielooporne bakterie Gram-ujemne (np. Pseudomonas aeruginonsa, Acinetobacter baumanii), beztlenowce, grzyby (7).

Specyficznym rodzajem są zakażenia powstałe w wyniku pogryzienia przez zwierzęta lub człowieka. Zakażenia te mogą mieć przebieg ciężki lub powikłany, co jest związane z szczególną mikroflorą jamy ustnej, zwłaszcza zwierząt. Leczenie przeciwdrobnoustrojowe jest wtedy konieczne, w szczególności u pacjentów $\mathrm{z}$ obniżoną odpornością, ranami twarzy lub rąk, $z$ uszkodzeniem okostnej lub torebki stawowej. Z wyboru stosuje się antybiotyki $\beta$-laktamowe z połączeniu $\mathrm{z}$ inhibitorami $\beta$-laktamaz. W przypadku uczulenia na penicylinę można zastosować schemat: trimetoprim/ sulfametoksazol lub fluorochinolon w skojarzeniu z klindamycyną lub metronidazolem. Dodatkowo w tej grupie zakażeń należy zawsze ocenić wskazania do poekspozycyjnej profilaktyki przeciwtężcowej oraz przeciw wściekliźnie $(7,19)$.

Terapia empiryczna niepowikłanych wodnopochodnych zakażeń skóry i tkanek miękkich obejmuje fluororchinolony, a w przypadku ekspozycji na słoną wodę należy zastosować doksycyklinę (7).

Leczenie przeciwdrobnoustrojowe u pacjentów hospitalizowanych trwa od 7 do 14 dni. Antybiotykoterapię dożylną można zastąpić doustną dopiero po uzyskaniu poprawy stanu klinicznego, zakończenia leczenia chirurgicznego oraz dobrej tolerancji leczenie doustnego. W przypadku leczenia pozaszpitalnego, niepowikłanych zakażeń skóry i tkanek miękkich czas antybiotykoterapii wynosi od $5-10 \mathrm{dni}(6,7,10)$.

Jednym z ważnych problemów u pacjentów z zakażeniem skóry i tkanki podskórnej jest ryzyko nawrotu. 
reduces the risk of relapse by $47 \%$ for up to 3 years $(6,20)$.
Zjawisko to obserwuje się przed wszystkim w przypadku czyraków, róży czy powierzchownego zapalenia tkanki łącznej (cellulitis) (Tab. II) (10).

Table II. Prevention of recurrent skin and soft tissue infections (10)

Tabela II. Profilaktyka nawracających zakażenia skóry i tkanek miękkich (10)

\begin{tabular}{|c|c|c|c|}
\hline Form of Infection & Risk factors & Aetiological factor & $\begin{array}{l}\text { Prophylactic treatment } \\
\text { after standard therapy of } \\
\text { acute infection }\end{array}$ \\
\hline Erysipelas / cellulitis & $\begin{array}{c}\text { Leg edema } \\
\text { Cancer surgery with lymph } \\
\text { node dissection } \\
\text { Radiotherapy } \\
\text { Obesity } \\
\text { Diabetes mellitus } \\
\text { Eczema } \\
\text { Immunosuppression }\end{array}$ & Streptococcus pyogenes & $\begin{array}{c}\text { Benzathine penicilli } \\
\text { Phenoxymethyl penicillin }\end{array}$ \\
\hline Furuncles & $\begin{array}{l}\text { Nasal carriage } \\
\text { Recurrent skin injuries } \\
\text { Hygiene negligence } \\
\text { Family spread }\end{array}$ & Staphylococcus aureus & $\begin{array}{c}\text { Mupirocin } \\
\text { (treatment of nasal carriage) } \\
\text { Chlorhexidine products for } \\
\text { external use } \\
\text { Doxycycline } \pm \text { rifampicin } \\
\text { Clindamycin }\end{array}$ \\
\hline $\begin{array}{c}\text { Changes in the structures of } \\
\text { the skin }\end{array}$ & $\begin{array}{l}\text { Genetic predisposition } \\
\text { (pilonidal cyst) } \\
\text { Sitting work } \\
\text { Anatomical predisposition }\end{array}$ & $\begin{array}{c}\text { Gram-negative rods } \\
\text { Anaerobes } \\
\text { Staphylococcus aureus }\end{array}$ & Surgical treatment \\
\hline
\end{tabular}

The selection of antibiotic/chemotherapeutic agent depending on the severity of skin and soft tissue infection is presented in Tables III and IV $(6,7)$.

Treatment regimen for selected forms of skin and soft tissue infections $(7,21)$ :
W związku z tym u pacjentów z co najmniej jednym wcześniejszym epizodem zapalenia tkanki łącznej zaleca się podawanie profilaktyczne doustnej penicyliny w dawce $250 \mathrm{mg} 2 \mathrm{x}$ dobę przez 6 miesięcy. Profilaktyka ta zmniejsza ryzyko nawrotu do 3 lat o $47 \%(6,20)$

Wybór antybiotyku/chemioterapeutyku w zależności od ciężkości zakażenia skóry i tkanek miękkich przedstawiono w tabelach III i IV $(6,7)$.

Schemat leczenia w wybranych postaciach zakażeń skóry i tkanek miękkich $(7,21)$ :

Table III. Choice of antibiotic (chemotherapeutic agent) for mild and moderate skin and soft tissue infections $(6,7)$

Tabela III. Wybór antybiotyku (chemioterapeutyku) w zakażeniach skóry i tkanek miękkich o przebiegu lekkim i umiarkowanym $(6,7)$

\begin{tabular}{|c|c|c|}
\hline $\begin{array}{l}\text { Antibiotic / } \\
\text { chemotherapeutic } \\
\text { agent }\end{array}$ & Indications & Posology \\
\hline $\begin{array}{l}\text { Amoxicillin/ } \\
\text { clavulanic acid }\end{array}$ & $\begin{array}{l}\text { Impetigo; biting; infections: } \\
\text { MSSA, E. coli, Klebsiella spp }\end{array}$ & $\begin{array}{l}\text { Adults: } 1 \mathrm{~g} \mathrm{q} 12 \mathrm{~h} \text { or } 625 \mathrm{mg} \text { q } 8 \mathrm{~h}(\mathrm{PO}) \\
\text { Children: } \\
\text { - under } 3 \text { months of age or less than } 40 \mathrm{~kg}: 25-45 \mathrm{mg} / \\
\text { kg b.w./day (of amoxicillin) in } 2 \text { doses } \\
\text { - over } 3 \text { months of age or more than } 40 \mathrm{~kg}: 30 \mathrm{~kg} / \mathrm{kg} \\
\text { b.w./day in } 2 \text { doses }\end{array}$ \\
\hline Cefazolin & MSSA infections, impetigo, bites & $\begin{array}{l}\text { Adults: } 500 \mathrm{mg}-1.5 \mathrm{~g} \mathrm{IV} \text { or IM q } 8 \mathrm{~h} \\
\text { Children: } 25-100 \mathrm{mg} / \mathrm{kg} \text { b.w./day IV or IM in } 3 \text { or } \\
4 \text { doses }\end{array}$ \\
\hline Cefalexin & MSSA infections, impetigo, bites & $\begin{array}{l}\text { Adults: } 500 \mathrm{mg} \text { q6h PO } \\
\text { Children: } 25-50 \mathrm{mg} / \mathrm{kg} \text { b.w./day in } 2 \text { doses }\end{array}$ \\
\hline
\end{tabular}




\begin{tabular}{|c|c|c|}
\hline Clindamycin & $\begin{array}{l}\text { Impetigo; infections: } \\
\text { MSSA, MRSA, Clostridium, bites }\end{array}$ & $\begin{array}{l}\text { Adults: } 600 \mathrm{mg} \mathrm{q} 8 \mathrm{~h} \text { PO or IV for } 7-14 \text { days } \\
\text { Children: } 16-20 \mathrm{mg} / \mathrm{kg} \text { b.w./day in } 3 \text { or } 4 \text { doses }\end{array}$ \\
\hline Cloxacillin & MSSA infections & 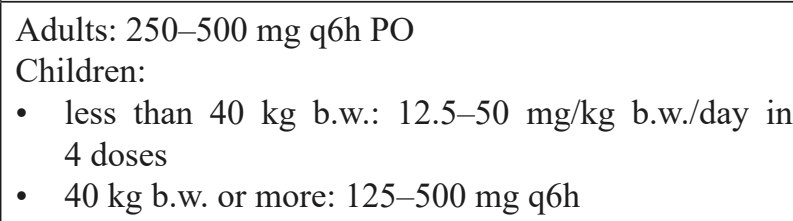 \\
\hline Doxycycline & MRSA infections; bites & $\begin{array}{l}\text { Adults: } 100 \mathrm{mg} \text { BID PO } \\
\text { Children over } 8 \text { years of age and weighing more than } \\
45 \mathrm{~kg}: 100 \mathrm{mg} \text { BID }\end{array}$ \\
\hline Fluoroquinolones & Bites & $\begin{array}{l}\text { Adults: } \\
\text { Ciprofloxacin } 500-750 \mathrm{mg} \text { BID PO or } 400 \mathrm{mg} \text { IV q12h }\end{array}$ \\
\hline Mupirocin & $\begin{array}{l}\text { Impetigo or folliculitis caused by } \\
\text { MRSA }\end{array}$ & $\begin{array}{l}\text { Apply } 2 \% \text { ointment } 3 \text { times a day for } 3-5 \text { days; not } \\
\text { recommended for children under } 2 \text { months of age }\end{array}$ \\
\hline Retapamulin & Impetigo caused by MSSA & $\begin{array}{l}\text { Apply } 1 \% \text { ointment twice a day for } 5 \text { days; not } \\
\text { recommended for children under } 9 \text { months of age }\end{array}$ \\
\hline $\begin{array}{l}\text { Trimethoprim/ } \\
\text { sulfamethoxazole }\end{array}$ & MRSA infections; bites & $\begin{array}{l}\text { Adults: } 960 \mathrm{mg} \text { q } 12 \mathrm{~h} \mathrm{PO} \\
\text { Children: } 8-12 \mathrm{mg} / \mathrm{kg} \text { b.w./day (of trimethoprim) in } \\
2 \text { doses (PO) or } 4 \text { doses (IV) }\end{array}$ \\
\hline
\end{tabular}

Table IV. Choice of antibiotic (chemotherapeutic agent) for necrotizing and other complicated skin and soft tissue infections $(6,7)$

Tabela IV. Wybór antybiotyku (chemioterapeutyku) w martwiczych lub powikłanych zakażeniach skóry i tkanek miękkich $(6,7)$

\begin{tabular}{|c|c|c|}
\hline $\begin{array}{c}\text { Antibiotic/ } \\
\text { chemotherapeutic } \\
\text { agent }\end{array}$ & Indications & Posology \\
\hline $\begin{array}{l}\text { Carbapenems: } \\
\text { Imipenem/cilastatin }\end{array}$ & & $\begin{array}{l}\text { Adults: } 1 \mathrm{~g} \mathrm{IV} \text { every } 6-8 \text { hours Children: } 25 \mathrm{mg} / \mathrm{kg} \text { b.w. } \\
\text { every 6-12 hours (up to } 4 \mathrm{~g} / \text { day) }\end{array}$ \\
\hline Meropenem & Mixed necrotic infections & $\begin{array}{l}\text { Adults: } 1 \text { g IV q } 8 \mathrm{~h} \\
\text { Children: } 10 \mathrm{mg} / \mathrm{kg} \text { b.w. } \mathrm{q} 8 \mathrm{~h} ; \text { in } P \text {. aeruginosa infections } \\
20 \mathrm{mg} / \mathrm{kg} \text { b.w. q } 8 \mathrm{~h}\end{array}$ \\
\hline Ertapenem & & $\begin{array}{l}\text { Adults: } 1 \mathrm{~g} \mathrm{IV} \mathrm{q} 24 \mathrm{~h} \text { Children: from } 3 \text { months to } 12 \text { years } \\
\text { of age: } 15 \mathrm{mg} / \mathrm{kg} \text { b.w. q12h }\end{array}$ \\
\hline Cefotaxime & $\begin{array}{l}\text { In combination with metronidazole } \\
\text { or clindamycin for empirical } \\
\text { treatment of mixed necrotizing } \\
\text { infections }\end{array}$ & $\begin{array}{l}\text { Adults: } 2 \mathrm{~g} \text { IV q6h } \\
\text { Children: } 50 \mathrm{mg} / \mathrm{kg} \text { b.w. q6h }\end{array}$ \\
\hline Ceftaroline & MRSA infection & Adults: $600 \mathrm{mg}$ IV q12h for 5-14 days \\
\hline Ceftriaxone & $\begin{array}{l}\text { Water-borne infection; in } \\
\text { combination with doxycycline in } \\
\text { infections caused by: Aeromonas } \\
\text { hydrophila or Vibrio vulnificus }\end{array}$ & $\begin{array}{l}\text { Adults: } 1-2 \mathrm{~g} \text { IV every } 24 \text { hours } \\
\text { Children: } 50-70 \mathrm{mg} \mathrm{kg} \text { b.w. IV every } 12 \text { or } 24 \text { hours (up } \\
\text { to } 2 \mathrm{~g} \text { daily) }\end{array}$ \\
\hline Dalbavancin & MSSA or MRSA infections & $\begin{array}{l}\text { Adults: initial dose }-1 \mathrm{~g} \mathrm{IV} \text {, subsequent dose }-500 \mathrm{mg} \\
\text { in } 7 \text { days }\end{array}$ \\
\hline Daptomycin & MRSA infections & Adults: $4 \mathrm{mg} / \mathrm{kg}$ b.w. IV q24h for $7-14$ days \\
\hline Doxycycline & $\begin{array}{l}\text { Water-borne infection; in } \\
\text { combination with ciprofloxacin or } \\
\text { ceftriaxone or cefotaxime }\end{array}$ & $\begin{array}{l}\text { Adults: } 100 \mathrm{mg} \text { IV q12h } \\
\text { Children: } \\
-\geq 8 \text { years of age and less than } 45 \mathrm{~kg} \text { b.w.: } 4 \mathrm{mg} / \mathrm{kg} \\
\text { b.w./day in } 2 \text { doses } \\
-\geq 8 \text { years of age and } \geq 45 \mathrm{~kg} \text { b.w: } 100 \mathrm{mg} \mathrm{IV} \mathrm{q} 12 \mathrm{~h}\end{array}$ \\
\hline
\end{tabular}




\begin{tabular}{|c|c|c|}
\hline Linezolid & MRSA infections & $\begin{array}{l}\text { Adults: } 600 \mathrm{mg} \text { IV q12h for } 7-14 \text { days } \\
\text { Children: } \\
\text { - } \geq 12 \text { years of age: } 600 \mathrm{mg} \text { IV q12h for } 10-14 \text { days } \\
\text { - } \quad<12 \text { years: } 10 \mathrm{mg} / \mathrm{kg} \text { b.w. q } 8 \mathrm{~h} \text { for } 10-14 \text { days }\end{array}$ \\
\hline Metronidazole & $\begin{array}{l}\text { In combination with cefotaxime } \\
\text { for empirical treatment of mixed } \\
\text { necrotizing infection }\end{array}$ & $\begin{array}{l}\text { Adults: } 600-900 \mathrm{mg} \text { IV q8h } \\
\text { Children: } 10-13 \mathrm{mg} / \mathrm{kg} \text { b.w. q8h }\end{array}$ \\
\hline Oritavancin & $\begin{array}{l}\text { MSSA; MRSA or Enterococcus } \\
\text { faecalis infections }\end{array}$ & Adults: $1.2 \mathrm{~g}$ IV as a single dose \\
\hline $\begin{array}{l}\text { Penicillin in } \\
\text { combination with } \\
\text { clindamycin }\end{array}$ & $\begin{array}{l}\text { Necrotizing fasciitis caused by } \\
\text { Streptococcus pyogenes; gas } \\
\text { gangrene }\end{array}$ & $\begin{array}{l}\text { Adults: } 2-4 \text { million units penicillin IV q6h }+600-900 \\
\text { mg clindamycin IV q } 8 \mathrm{~h} \\
\text { Children: } 60,000-100,000 \text { units } / \mathrm{kg} \text { b.w. penicillin IV } \\
\text { q6h }+10-13 \mathrm{mg} / \mathrm{kg} \text { b.w./day clindamycin IV in } 3 \text { doses }\end{array}$ \\
\hline $\begin{array}{l}\text { Piperacillin/ } \\
\text { tazobactam }\end{array}$ & $\begin{array}{l}\text { First-line antibiotic for mixed } \\
\text { necrotizing infection }\end{array}$ & $\begin{array}{l}\text { Adults: } 3.375 \mathrm{~g} \text { IV every } 6-8 \text { hours } \\
\text { Children: } 60-75 \mathrm{mg} / \mathrm{kg} \text { b.w. (piperacillin) IV every } \\
6 \text { hours }\end{array}$ \\
\hline Telavancin & MSSA or MRSA infections & Adults: $10 \mathrm{mg} / \mathrm{kg}$ b.w. every 24 hours for $7-14$ days \\
\hline Tigecycline & MRSA infection & $\begin{array}{l}\text { Adults: initial dose } 100 \mathrm{mg} \text {, followed by } 50 \mathrm{mg} \text { IV q } 12 \mathrm{~h} \\
\text { for } 5-14 \text { days }\end{array}$ \\
\hline Vancomycin & MRSA infection & $\begin{array}{l}\text { Adults: } 15 \mathrm{mg} / \mathrm{kg} \text { b.w. q12h } \\
\text { Children: } 10 \mathrm{mg} / \mathrm{kg} \text { b.w. IV q6h }\end{array}$ \\
\hline
\end{tabular}

\section{Impetigo}

- topically: mupirocin, retapamulin, fucidin

- systemic treatment: (in the absence of improvement after topical treatment): cloxacillin, cefalexin, clarithromycin, azithromycin, clindamycin, amoxicillin/clavulanic acid

\section{Furuncles / furunculosis / abscesses}

surgical treatment (incision + drainage) + empiric antibiotic therapy

- mild or moderate course: clindamycin or cotrimoxazole or doxycycline severe course: vancomycin or teicoplanin or daptomycin or dalbavancin or linezolid or tigecycline

Targeted treatment

- MSSA: cloxacillin, cefazolin, clindamycin

- MRSA: vancomycin, dalbavancin, linezolid, daptomycin, ceftaroline

\section{Erysipelas}

- mild/moderate course: phenoxymethyl penicillin, cloxacillin, cefalexin, amoxicillin with clavulanic acid, clindamycin

- severe course: penicillin G, clindamycin combined with penicillin or ceftriaxone, dalbavancin, vancomycin + piperacillin/tazobactam

\section{Superficial cellulitis:}

- mild course: benzathine penicillin, 1st or 2nd generation cephalosporin, cloxacillin, clindamycin, levofloxacin, cotrimoxazole

- moderate course: ceftriaxone, cefazolin, clindamycin, moxifloxacin

- severe course: surgical treatment + piperacillin/ tazobactam or carbapenem

\section{Liszajec}

- miejscowo: mupirocyna, retapamulina, fucydyna

- leczenie ogólne: (przy braku poprawy po leczeniu miejscowym): kloksacylina, cefaleksyna, klarytromycyna, azytromycyna, klindamycyna, amkosycylina z kwasem klawulanowym

\section{Czyraki / czyraczność / ropnie}

opracowanie chirurgiczne (nacięcie + drenaż) + antybiotykoterapia empiryczna

- przebieg lekki lub umiarkowany: klindamycyna lub kotrimoksazol lub doksycyklina

- przebieg ciężki: wankomycyna lub teikoplanina lub daptomycyna lub dalbawancyna lub linezolid lub tygecyklina

Leczenie celowane

- MSSA: kloksacylina, cefazolina, klindamycyna

- MRSA: wankomycyna, dalbawancyna, linezolid, daptomycyna, ceftarolina

\section{Róża}

- przebieg lekki / umiarkowany: penicylina fenoksymetylowa, kloksacylina, cefaleksyna, amoksycylina z kwasem klawualnowym, klindamycyna

- przebieg ciężki: penicylina $G$, klindamycyna w skojarzeniu z penicylina lub ceftriaksonem, dalbawancyna, wankomycyna + piepracylina/ tazobaktam

4. Powierzchowne zapalenie tkanki łącznej (cellulitis):

- przebieg lekki: penicylina benzatynowa, cefalosporyna I lub II generacji, kloksacylina, klinda- 


\section{Necrotizing skin and soft tissue infections}

Urgent surgical treatment + antibiotic therapy:

- empiric:

- piperacillin/tazobactam + vancomycin or linezolid

- imipenem or meropenem + linezolid

- 3rd or 4th generation cefalosporin + metronidazole or clindamycin

- aminoglycoside + metronidazole

- targeted:

- Streptococcus pyogenes: penicillin + clindamycin, vancomycin, linezolid, daptomycin, dalbavancin

- Staphylococcus aureus:

- MSSA: cloxacillin, cefazolin, clindamycin, dalbavancin

- MRSA: vancomycin+ rifampicin, linezolid + rifampicin, daptomycin, dalbavancin

- Clostridium spp.: penicillin G + metronidazole, penicillin + clindamycin, carbapenem \pm clindamycin, vancomycin + piperacillin/tazobactam or ampicillin/ sulbactam

- Aeromonas hydrophila: doxycycline + ciprofloxacin/ceftriaxone

- Vibrio vulnificus: doxycycline + ceftriaxone/ cefotaxime

\section{Hypersensitivity to penicillin:}

- skin reactions only: cefepime + metronidazole

- anaphylaxis: vancomycin, dalbavancin, daptomycin, ciprofloxacin + metronidazole

\section{REFERENCES}

1. Hersh AL, Chambers HF, Maselli JH, et al. National trends in ambulatory visits and antibiotic prescribing for skin and soft-tissue infections. Arch Intern Med. 2008;28;168(14):1585-91.

2. Esposito S, Noviello S, Leone S. Epidemiology and microbiology of skin and soft tissue infections. Curr Opin Infect Dis. 2016;29(2):109-15.

3. Miller LG, Eisenberg DF, Liu H. Incidence of skin and soft tissue infections in ambulatory and inpaptient dettings, 2005-2010. BMC Infect Dis. 2015; 15:362.

4. Pallin DJ, Egan DJ, Pelletier AJ, et al. Increased US emergency department visits for skin and soft tissue infections, and changes in antibiotic choices, during the emergence of community-associated methicillin-resistant Staphylococcus aureus. Ann Emerg Med. 2008;51(3):291-8.

5. Esposito S, Leone S, Petta, et al. Skin and soft tissue infections: classification and epidemiology. Infez Med. 2009;17(Suppl.4):6-17. mycyna, lewofloksacyna, kotrimoksazol

- przebieg umiarkowany: ceftriakson, cefazolina, klindamycyna, moksyfloksacyna

- przebieg ciężki: opracowanie chirurgiczne + piperacylina/tazobaktam lub karbapenem

\section{Martwicze zakażenia skóry i tkanki lącznej}

Pilne opracowanie chirurgiczne + antybiotykoterapia:

- empiryczna:

- piperacylina/tazobaktam + wankomycyna lub linezolid

- imipenem lub meropenem + linezolid

- cefalsporyna III lub IV generacji + metronidazol lub klindamycyna

- aminoglikozyd + metronidazol

- celowana:

- Streptococcus pyogenes: penicylina + klindamycyna, wankomycyna, linezolid, daptomycyna, dalbawancyna

- Staphylococus aureus:

- MSSA: kloksacylina, cefazolina, klindamycyna, dalbawancyna

- MRSA: wankomvcyna + rifampicyna, linezolid + rifampicyna, daptomycyna, dalbawancyna

- Clostridium spp.: penicylina $\mathrm{G}+$ metronidazol, penicylina + klindamycyna, karbapenem + ew. klindamycyna, wankomycyna + piperacylina/ tazobaktam lub ampicylina/sulbaktam

- Aeromonas hydrophila: doksycyklina+ ciprofloksacyna/ceftriakson

- Vibrio vulnificius: doksycyklina + ceftriakson/ cefotaksym

\section{Nadwrażliwość na penicylinę:}

- tylko reakcje skórne: cefepim + metronidazol

- anafilaksja: wankomycyna, dalbawancyna, daptomycyna, ciprofloksacyna + metronidazol

6. Ramakrishnan K, Salinas RC, Higuita NIA. Skin and soft tissue infections. Am Fam Physician 2015;92:474-483.

7. Stevens DL, Bisno AL, Chambers HF, et al. Practice guidelines for the diagnosis and management of skin and soft tissue infections: 2014 update by the Infections Diseases Society of America. Clin Infect Dis. 2014;59:147-159.

8. Eron LJ, Lipsky BA, Low DE, et al. Managing skin and soft tissue infections: expert panel recommendations on key decision points. J Antimicrob Chemother. 2003;52 Suppl 1:i3-17.

9. Suaya JA, Eisenberg DF, Fang C, et al. Skin and soft tissue infections and associated complications among commercially insured patients aged 0-64 
years with and without diabetes in the U.S. PLoS One. 2013 Apr 10;8(4):e60057

10. Esposito S, Bassetti M, Concia E, et al. Diagnosis and management of skin and soft-tissue infections (SSTI).A literature review and consensus statement: an update. J Chemother. 2017 Aug;29(4):197-214.

11. Ki V, Rotstein C. Bacterial skin and soft tissue infections in adults: A review of their epidemiology, pathogenesis, diagnosis, treatment and site of care. Can J Infect Dis Med Microbiol. 2008 Mar;19(2):173-84

12. Jeng A, Beheshti M, Li J, et al. The role of beta-hemolytic streptococci in causing diffuse, nonculturable cellulitis: a prospective investigation. Medicine (Baltimore). 2010;89(4):217-26.

13. Moet GJ, Jones RN, Biedenbach DJ, et al. Contemporary causes of skin and soft tissue infections in North America, Latin America, and Europe: report from the SENTRY Antimicrobial Surveillance Program (1998-2004). Diagn Microbiol Infect Dis. 2007;57(1):7-13.

14. Malghem J, Lecouvet FE, Omoumi $P$, et al. Necrotizing fasciitis: contribution and limitations of diagnostic imaging. Joint Bone Spine. 2013 Mar;80(2):146-54.

15. Wong CH, Khin LW, Heng KS, et al. The LRINEC (Laboratory Risk Indicator for Necrotizing Fasciitis) score: a tool for distinguishing necrotizing fasciitis from other soft tissue infections. Crit Care Med. 2004;32(7):1535-41.

16. Esposito S, De Simone G, Gioia R, et al. Deep tissue biopsy vs superficial swab culture, including microbial loading determination, in the microbiological assessment of skin and soft tissue infections (SSTIs). J Chemiother 2016;47:1-5.

17. Kallstrom G. Are quantitative bacterial wound cultures useful? J Clin Microbiol 2014;52:27532756.

18. Hankin A, Everett WW. Are antibiotics necessary after incision and drainage of a cutaneous abscess?Ann Emerg Med. 2007;50(1):49-51.

19. Ellis R, Ellis C. Dog and cat bites. Am Fam Physician. 2014;15;90(4):239-43.

20. Dalal A, Eskin-Schwartz M, Mimouni D, et al. Interventions for the prevention of recurrent erysipelas and cellulitis. Cochrane Database Syst Rev. 2017;20;6:CD009758. doi: 10.1002/14651858.CD009758.pub2.

21. Dzierżanowska D. Antybiotykoterapia praktyczna. Wyd 6. Bielsko-Biała: Alfa Medica Press; 2018: strony od 689 do 704 .

Received: 22.01 .2020

Accepted for publication: 30.03 .2020

Otrzymano: 22.01.2020 r.

Zaakceptowano do publikacji: 30.03.2020 r.

\section{Adres do korespondencji:}

Address for correspondence:

Prof. dr hab. med. Aleksander M. Garlicki

Klinika Chorób Zakaźnych i Tropikalnych, Uniwersytet Jagielloński Collegium Medicum ul. Jakubowskiego 2, 30-688 Kraków

tel. 124002000

e-mail: agarlicki@gmail.com 